\title{
Blueberry Germplasm Screening at Several Soil pH Regimes. II. Plant Nutrient Composition
}

\author{
Chad E. Finn', Carl J. Rosen, James J. Luby, and Peter D. Ascher \\ Department of Horticultural Science, University of Minnesota, St. Paul, MN 55108 \\ Additional index words. Vaccinium corymbosum, Vaccinium angustifolium, V. corymbosum/V. angustifolium hybrid deriva- \\ tives, $\mathrm{pH}$ tolerance
}

\begin{abstract}
Seedlings from crosses among Vaccinium corymbosum L., V. angustifolium Ait, and $V$. corymbosum/V. angustifolium hybrid-derivative parents, and micropropagated 'Northblue', 'Northsky', and 'Northcountry' plants, were grown for 2 years at Becker, Minn., in low (5.0) and high (6.5) soil pH regimes. Nutrient composition expressed as a concentration and total content was determined for $\mathrm{P}, \mathrm{K}, \mathrm{Ca}, \mathrm{Mg}, \mathrm{Fe}, \mathrm{Mn}, \mathrm{Zn}, \mathrm{Cu}$, and $\mathrm{B}$ in the aboveground portion of the plant. Except for $\mathrm{Fe}$, the $\mathrm{pH}$ regime effects on aboveground plant nutrient concentration and total content were much larger than population or population $\times \mathrm{pH}$ regime interaction effects. Population $\times \mathrm{pH}$ regime interactions were detected for all nutrients expressed as a concentration, except for $P$. Generalizations about plant performance and nutrient concentration of the plant could only be made in the context of a given $\mathrm{pH}$ regime. At low $\mathrm{pH}, \mathrm{P}$ and $\mathrm{Mn}$ tissue concentrations increased and $\mathrm{Ca}, \mathrm{Mg}$, and $\mathrm{B}$ concentrations decreased as the percentage of lowbush ancestry increased. At high $\mathrm{pH}, \mathrm{K}, \mathrm{Cu}$, and $\mathrm{B}$ concentrations decreased as the percentage of lowbush ancestry increased. Overall plant performance on the higher pH soils appeared to be positively correlated to aboveground tissue concentrations of $\mathrm{Mn}, \mathrm{K}$, and $\mathrm{Cu}$. When expressed as total content, population $\times \mathbf{p H}$ regime effects were only significant for tissue Mn. Differences in total nutrient content attributed to soil pH were primarily related to differences in plant dry weight.
\end{abstract}

Blueberry plants require an acidic soil high in organic matter, with relatively low nutrient inputs in commercial production (Galletta, 1975; Korcak et al., 1982). Acidifying soil amendments, which can be expensive and provide only short-term solutions to higher $\mathrm{pH}$ soils, are used to modify the soil for successful blueberry growth. Recently, studies have been conducted to better understand the variables involved in developing blueberry plants adapted to a wider range of physical and chemical soil properties (Finn et al., 1993; Korcak, 1989; Korcak et al., 1982; Rosen and Luby, 1987). Vaccinium angustifolium has been suggested as being more tolerant of upland soils (which usually have higher $\mathrm{pH}$ ) than $V$. corymbosum, as well as being a source of adaptation to northern climates (Galletta, 1975; Korcak, 1986a; 1989; Korcak et al., 1982; Rosen and Luby, 1987).

Several researchers have studied factors affecting the nutrient status of $V$. angustifolium, $V$. corymbosum, and hybrids of these species. Most research has focused on leaf nutrient concentration under ideal nutrient conditions (Korcak, 1986b; Korcak et al., 1982; Rosen and Luby, 1987), at various pH levels in containers (Cain, 1954; Hall et al., 1964; Townsend, 1969; 1971), or on various soil types (Chandler et al., 1985; Hall et al., 1964; Haynes and Swift, 1986; Korcak, 1986b, Korcak et al., 1982; Reich et al., 1982). We found no field studies that have examined nutrient concentration and total nutrient content under various soil $\mathrm{pH}$ regimes.

The foliar nutrient composition of highbush, lowbush, and species-hybrid derivatives has been shown to differ (Ballinger, 1966; Chandler et al., 1984; Korcak, 1986b; 1988; 1989; Korcak

Received for publication 20 Apr. 1992. Accepted for publication 30 Oct. 1992. Minnesota Agr. Expt. Sta. Scientific Journal Series Paper no. 20,091. We gratefully acknowledge the donation of micropropagated plants by Minn Vitro, St. Paul, Minn. This research was supported, in part, by U.S. Dept. Agr. Specific Cooperative Agreement no. 58-32U4-7-047. The cost of publishing this paper was defrayed in part by the payment of page charges. Under postal regulations, this paper therefore must be hereby marked advertisement solely to indicate this fact. ${ }^{1}$ Current address: USDA-ARS, Horticultural Crops Research Lab, 3420 NW Orchard Ave., Corvallis, OR 97330. et al., 1982; Rosen and Luby, 1987). Hall et al. (1964) reported that the foliar $\mathrm{Mn}$ concentration in $V$. angustifolium, at optimal $\mathrm{pH}$ levels, was up to 10 times the level that Eck (1988) reported as being excessive in $V$. corymbosum. Based on this striking difference and the hypothesis that $V$. angustifolium might be more tolerant of higher $\mathrm{pH}$, researchers have attempted to identify potential relationships between nutrient composition and $\mathrm{pH}$ tolerance. Hall et al. (1964) found in $V$. angustifolium that $\mathrm{Ca}, \mathrm{Mg}$, and $\mathrm{Fe}$ concentrations increased or were unchanged, and $\mathrm{P}, \mathrm{K}$, and $\mathrm{Mn}$ concentrations and plant dry weight decreased as $\mathrm{pH}$ level increased. However, all total nutrient content levels, a function of plant dry weight, were lower at higher $\mathrm{pH}$. Recently, Gupton and Spiers (1992) reported that heritability estimates for $V$. ashei crosses were high for tissue concentrations of $\mathrm{Mn}, \mathrm{Zn}, \mathrm{Ca}, \mathrm{Mg}$, and $\mathrm{K}$. Genetic correlations between elemental concentrations and visual ratings also were observed.

Rosen and Luby (1987) reported variations in foliar elemental composition in $V$. angustifolium, $V$. corymbosum, and $V$. Corymbosum $/ V$. angustifolium hybrid derivatives and progenies derived from them. These authors identified parents whose progenies tended to accumulate higher or lower concentrations of various nutrients and determined that the leaf concentration of various nutrients could be related to the percent lowbush ancestry of a progeny or parent. These conclusions, along with those of Korcak et al. (1982) and Brown and Draper (1980), who examined largely highbush progenies, suggested that nutrient concentration and total content can vary among Vaccinium spp. and may provide an additional selection criterion for identifying genotypes tolerant of higher $\mathrm{pH}$.

In a companion paper, we reported that blueberry seedlings produced from crosses among $V$. corymbosum, $V$. angustifolium, and $V$. corymbosum/ $V$. angustifolium hybrid derivative parents varied in growth and development when grown for two seasons under three soil $\mathrm{pH}$ regimes $(\mathrm{pH} \approx 5.0,5.5$, and 6.5 ) (Finn et al., 1993). The objectives of this study were to 1) characterize the influence of $V$. angustifolium ancestry and soil $\mathrm{pH}$ on the nutrient status of progenies, and 2) determine whether a relationship exists between nutrient status and performance on a higher $\mathrm{pH}$ soil. 
Table 1. Ancestry of blueberry cultivars and populations.

\begin{tabular}{|c|c|}
\hline Cultivar/population (ancestry) $^{\mathbf{2}}$ & $\begin{array}{c}\text { Lowbush } \\
(\%)\end{array}$ \\
\hline Northsky (B-6 × R2P4) & 25 \\
\hline Northcountry (B-6 $\times$ R2P4) & 25 \\
\hline Northblue (B-10 × US-3) & 25 \\
\hline $8634(\mathrm{MN}-61 \times$ Spartan $)$ & 25 \\
\hline 8641 (GR-1 × Spartan) & 25 \\
\hline $8619(\mathrm{MN}-61 \times$ Northblue $)$ & 33 \\
\hline 8645 (Northblue $\times$ GR-1) & 33 \\
\hline 8603 (Spartan x GRVa.) & 50 \\
\hline $8616($ N70249 $\times$ Spartan $)$ & 50 \\
\hline $8628(\mathrm{~N} 70249 \times \mathrm{B}-16)$ & 50 \\
\hline 8617 (N70249 $\times$ Northblue) & 62 \\
\hline $8602(\mathrm{MN}-61 \times$ GRVa.) & 75 \\
\hline $8605($ GR- $1 \times$ GRVa. $)$ & 75 \\
\hline $85306\left[(\mathrm{~N} 70249 \times \mathrm{B}-22) \mathrm{OP}^{\mathrm{y}}\right]$ & 75 \\
\hline $85319\left(\mathrm{GR} 4-32 \mathrm{OP}^{\mathrm{y}}\right)$ & 100 \\
\hline 85335 (GR11-36 OP') & 100 \\
\hline $85336\left(\mathrm{GR} 12-28 \mathrm{OP}^{\mathrm{y}}\right)$ & 100 \\
\hline $86200(\mathrm{~N} 7068 \times \mathrm{N} 7084)$ & 100 \\
\hline $86205(\mathbf{N} 7068 \times \mathbf{N} 70146)$ & 100 \\
\hline $86206(\mathrm{~N} 7068 \times \mathrm{N} 70153$ & 100 \\
\hline $86216(\mathrm{~N} 7094 \times \mathrm{N7084})$ & 100 \\
\hline $86261(\mathrm{~N} 70119 \times \mathrm{N} 7094)$ & 100 \\
\hline $86265(\mathrm{~N} 70119 \times \mathrm{N} 70146)$ & 100 \\
\hline $86283(\mathrm{~N} 70153 \times \mathrm{N} 7098)$ & 100 \\
\hline $86287(\mathrm{~N} 70153 \times \mathrm{N} 70146)$ & 100 \\
\hline
\end{tabular}

${ }^{\mathrm{T}}$ For further information on parents refer to Firm et al. (1993).

${ }^{y} \mathrm{OP}=$ open pollinated in a collection of $V$. angustifolium.

\section{Materials and Methods}

The diverse group of Vaccinium germplasm evaluated in this study included 22 populations and three cultivars (Table 1). Blueberry seeds from the various populations were sown in Dec. 1986 on sphagnum peat under mist in the greenhouse. Seedlings and rooted microcuttings of the cultivars were transplanted into $150-\mathrm{cm}^{3}$ peat pots filled with a sphagnum peat/Pro-mix media and grown until 1 June 1987, in the greenhouse. The seedlings were moved to an outdoor lath house 2 weeks before planting for acclimation to field conditions. Seedlings ranged from 10 to $30 \mathrm{~cm}$ tall at planting on 23 June 1987. The cultivar plants were about the same size as the seedlings at planting.

The planting was located at the Sand Plain Research Farm in Becker, Minn., on a Hubbard loamy sand (sandy, mixed, Udorthentic Haploborolls) with $2 \%$ to $3 \%$ organic matter and $\mathrm{pH} 5.5$ (1: 1, soil: water paste). Other initial soil chemical properties are provided by Finn et al. (1993), The site was divided into four blocks and, within each block, three $\mathrm{pH}$ regimes were randomly assigned to $9 \times 15 \mathrm{~m}$ sections, Culture practices have been described previously (Finn, et al,, 1993). Soil $\mathrm{pH}$ was monitored from pretreatment through planting, until the plants were harvested from the field. Low $(\mathrm{pH}$ $\approx 5.0)$ and high $(\mathrm{pH} \approx 6.5) \mathrm{pH}$ regimes were established in Oct. 1986. Ground dolomitic limestone equivalent to $10.9 \mathrm{t} \cdot \mathrm{ha}^{-1}$ and $\mathrm{FeSO}_{4} \cdot 7 \mathrm{H}_{2} \mathrm{O}(20 \% \mathrm{Fe})$ equivalent to $5.4 \mathrm{t} \cdot \mathrm{ha}^{-1}$ were incorporated to establish the low and high $\mathrm{pH}$ regimes, respectively. An additional $7.1 \mathrm{t} \cdot \mathrm{ha}^{-1}$ of lime was incorporated into the high $\mathrm{pH}$ regime in May 1987. In contrast to experiments reported in the companion paper (Finn et al., 1993) where growth and development were compared under three $\mathrm{pH}$ regimes, nutritional status was characterized only at the low and high $\mathrm{pH}$ levels

The entire aboveground portion from each plant (stems and leaves), harvested on 7 Sept. 1988, was rinsed in tap water, then in distilled water, and oven dried at $60 \mathrm{C}$ for at least $48 \mathrm{~h}$. All plants (2-5) from each population within each $\mathrm{pH}$ regime block were combined and ground to pass a $1.0 \mathrm{~mm}$ sieve. Tissue samples (1 g) were dry ashed at 500C overnight, and the ash was dissolved in $10 \mathrm{ml} 2 \mathrm{~N} \mathrm{HCl}$. Tissue nutrient concentrations (milligrams nutrient per kilograms tissue dry weight) of $\mathrm{P}, \mathrm{K}, \mathrm{Ca}, \mathrm{Mg}, \mathrm{Fe}, \mathrm{Mn}, \mathrm{Zn}, \mathrm{B}$, and $\mathrm{Cu}$ were determined by inductively coupled plasma emission spectroscopy (Munter et al., 1984). Because of limited plant material in the high $\mathrm{pH}$ regime, $\mathrm{N}$ and $\mathrm{S}$ determinations were not made. Total nutrient content per plant (grams nutrient per plant) was computed as nutrient concentration (grams nutrient per grams tissue dry weight) multiplied by the average population dry weight (grams tissue dry weight per plant).

Soil samples from each plot (six cores per plot) were collected in the interval from 0 to $15 \mathrm{~cm}$. After air drying, soil $\mathrm{pH}$ was determined in a soil: water (1:1) paste; soil $\mathrm{P}$ was determined using the Bray P1 extractant (Bray and Kurtz, 1945); soil Ca, Mg, and K

Table 2. Selected soil chemical properties for soils collected at termination of the experiment from high $(6.5 \pm 0.3)$ and low $(5.0 \pm 0.2) \mathrm{pH}$ regimes. ${ }^{2}$

\begin{tabular}{lcccccccc}
\hline \hline Regime & $\mathrm{P}$ & $\mathrm{K}$ & $\mathrm{Ca}$ & $\mathrm{Mg}$ & $\mathrm{Fe}$ & $\mathrm{Mn}$ & $\mathrm{Zn}$ & $\mathrm{Cu}$ \\
\hline High & $61 \pm 19$ & $65 \pm 17$ & $1279 \pm 370$ & $78 \pm 8$ & $21 \pm 1$ & $10 \pm 3$ & $0.6 \pm 0.1$ & $1.9 \pm 0.5$ \\
Low & $45 \pm 4$ & $60 \pm 10$ & $366 \pm 85$ & $52 \pm 16$ & $79 \pm 11$ & $39 \pm 3$ & $0.8+0.1$ & $1.9 \pm 0.2$ \\
\hline
\end{tabular}

${ }^{\overline{2}}$ Mean and SD of four replications.

Table 3. Mean square probability values (ANOVA F-tests) for treatment effects and interactions for $\log _{10}$ dry weight, nutrient concentration, and $\log _{10}$ total nutrient content.

\begin{tabular}{|c|c|c|c|c|c|c|c|c|c|c|c|}
\hline Source & $\mathrm{df}$ & Dry wt & $\mathrm{P}$ & $\mathbf{K}$ & $\mathrm{Ca}$ & $\mathrm{Mg}$ & $\mathrm{Fe}$ & $\mathrm{Mn}$ & $\mathrm{Zn}$ & $\mathrm{Cu}$ & B \\
\hline \multicolumn{12}{|c|}{ Nutrient concn } \\
\hline pH regime & 1 & 0.05 & 0.06 & 0.04 & 0.02 & 0.04 & 0.98 & 0.01 & 0.03 & 0.01 & 0.03 \\
\hline Population (pop.) & 24 & 0.01 & 0.01 & 0.01 & 0.01 & 0.01 & 0.01 & 0.01 & 0.01 & 0.01 & 0.01 \\
\hline pH regime $\times$ pop. & 24 & 0.34 & 0.24 & 0.02 & 0.01 & 0.06 & 0.09 & 0.01 & 0.01 & 0.01 & 0.01 \\
\hline \multicolumn{12}{|c|}{ Total content } \\
\hline pH regime & 1 & & 0.05 & 0.05 & 0.07 & 0.06 & 0.04 & 0.02 & 0.08 & 0.03 & 0.04 \\
\hline Pop. & 24 & & 0.01 & 0.01 & 0.01 & 0.01 & 0.01 & 0.01 & 0.01 & 0.01 & 0.01 \\
\hline pH regime $\times$ pop & 24 & & 0.18 & 0.13 & 0.32 & 0.46 & 0.17 & 0.01 & 0.15 & 0.15 & 0.26 \\
\hline
\end{tabular}


were determined in ammonium acetate extracts (Thomas, 1982); and $\mathrm{Fe}, \mathrm{Mn}, \mathrm{Cu}$, and $\mathrm{Zn}$ were determined in DTPA (diethylenetriamine pentaacetic acid) extracts (Lindsay and Norvell, 1978).

Analyses of variance were computed for a randomized complete block with split plots, where $\mathrm{pH}$ regime served as main plots and populations as subplots (Finn et al., 1993). The variation between $\mathrm{pH}$ levels for dry weight and total nutrient content was large and, therefore, the logarithmically transformed (base 10) values were analyzed (Steel and Torrie, 1980). For simplicity, data are presented as the antilog of the transformed means.

\section{Results and Discussion}

At the end of the experiment, concentrations of ammonium acetate extractable $\mathrm{Ca}$ and $\mathrm{Mg}$ and Bray $\mathrm{Pl}$ extractable $\mathrm{P}$ were higher in the high $\mathrm{pH}$ (lime-amended) soils, while DTPA extractable $\mathrm{Fe}$ and $\mathrm{Mn}$ concentrations were higher in the low $\mathrm{pH}$ (iron sulfate-amended) soils (Table 2). An unavoidable confounding effect of these soil amendments was that $\mathrm{pH}$ changes were also associated with changes in soil elemental concentrations. These differences must be kept in mind when comparing the effects of $\mathrm{pH}$ on nutritional status, our first objective. However, for our second objective, comparisons of interest were primarily those within a $\mathrm{pH}$ regime.

Differences in aboveground dry weight were significant for population and $\mathrm{pH}$ regime, and the interaction effect was nonsignificant (Table 3 ). The variation among populations was significant for concentration and total content for each nutrient. Except for $\mathrm{Fe}$ concentration, the $\mathrm{pH}$ regime effects were also significant for all nutrients. Population $\times \mathrm{pH}$ regime interactions for nutrients concentration were significant $(P \leq 0.10)$ for all elements except for $\mathrm{P}$, while for total content, they were only significant for Mn. For aboveground dry weight and for all nutrients except $\mathrm{Fe}$, the $\mathrm{pH}$ treatment had an overriding effect on nutrient concentration and total nutrient content, since the mean squares resulting from $\mathrm{pH}$ regime effects were much larger than mean squares for population effects or the population $\times \mathrm{pH}$ regime interaction (data not shown).

Although tissue $\mathrm{Fe}$ concentrations were similar at both $\mathrm{pH}$ levels, they were high (Table 4), which suggests contamination of the samples with Fe from soil that may not have washed off during preparation. Average aluminum concentrations in aboveground tissues were also high $\left(>450 \mathrm{mg} \cdot \mathrm{kg}^{-1}\right)$, suggesting soil contamination (Jones et al., 1991). Although poor growth on high $\mathrm{pH}$ soils and chlorosis in blueberries is believed to be related to iron nutrition, tissue concentrations of Fe are not highly correlated with these symptoms (Cain, 1954; Gupton and Spiers, 1992; Korcak, 1989).

Despite significant differences in plant nutrient concentrations because of $\mathrm{pH}$ (Table 4), dry-weight accumulation was several fold higher at low $\mathrm{pH}$ and had an overriding effect on total nutrient content. Thus, plants grown under the low $\mathrm{pH}$ regime had a higher total content of all nutrients than those grown at high $\mathrm{pH}$ (Table 5).

Although Korcak (1988) found that stem and leaf nutrient concentrations differed, the aboveground tissue nutrient concentrations under the low $\mathrm{pH}$ regime (Table 4) were similar to leaf concentrations in blueberries with similar ancestry, grown on native soil in the same field (Rosen and Luby, 1987). The nutrient concentrations in aboveground tissue (stems and leaves combined) at low $\mathrm{pH}$ were within the same range as leaf concentrations of $\mathrm{Mg}, \mathrm{Mn}, \mathrm{Cu}$, and $\mathrm{B}$ measured on plants grown on unamended soil at this site, but were lower for $\mathrm{P}$ and $\mathrm{K}$, higher for $\mathrm{Ca}$ and $\mathrm{Zn}$, and much higher for Fe (Rosen and Luby, 1987).

The large number of populations made it impractical to plot or tabulate all $\mathrm{pH} \times$ population interactions for all nutrients. Therefore, to address our objective on the relationship between $V$. angustifolium ancestry and $\mathrm{pH}$ tolerance, the populations were separated into groups based on percent lowbush ancestry. In addition, the correlations between the percent lowbush ancestry and either nutrient concentration or total content were calculated within each $\mathrm{pH}$ regime (Tables 4 and 5). The number of populations (or cultivars) within each percent lowbush classification were as follows: $25 \%$ to $33 \%$, seven populations; $50 \%$ to $75 \%$, seven populations; and 100\%, 11 populations (Table 1).

At low $\mathrm{pH}$, the concentration of $\mathrm{P}$ and $\mathrm{Mn}$ increased as the percent lowbush ancestry increased. However, $\mathrm{Ca}, \mathrm{Mg}$, and $\mathrm{B}$ concentrations decreased (Table 4). In contrast, at pH 5.0, Rosen and Luby (1987) found a highly significant positive correlation of

Table 4. Dry weight and nutrient concentrations in aboveground portion of blueberry plants grown at high (6.5) and low (5.0) $\mathrm{pH}$.

\begin{tabular}{|c|c|c|c|c|c|c|c|c|c|c|c|c|c|c|c|c|c|c|c|c|}
\hline \multirow[b]{4}{*}{ Effect } & & & \multicolumn{18}{|c|}{ Nutrient concn } \\
\hline & & & \multicolumn{8}{|c|}{$\left(\mathrm{g} \cdot \mathrm{kg}^{-1}\right)$} & \multicolumn{10}{|c|}{$\left(\mathrm{mg} \cdot \mathrm{kg}^{-1}\right)$} \\
\hline & \multicolumn{2}{|c|}{ Dry wt (g) } & \multirow{2}{*}{$\begin{array}{c}\mathrm{P} \\
\text { low }\end{array}$} & \multirow{2}{*}{$\begin{array}{c}P \\
\text { high }\end{array}$} & \multirow{2}{*}{$\begin{array}{c}\mathrm{K} \\
\text { low }\end{array}$} & \multirow{2}{*}{$\begin{array}{c}\text { K } \\
\text { high }\end{array}$} & \multirow{2}{*}{$\begin{array}{l}\mathrm{Ca} \\
\text { low }\end{array}$} & \multirow{2}{*}{$\begin{array}{c}\mathrm{Ca} \\
\text { high }\end{array}$} & \multirow{2}{*}{$\begin{array}{l}\mathrm{Mg} \\
\text { low }\end{array}$} & \multirow{2}{*}{$\begin{array}{r}\mathrm{Mg} \\
\text { high }\end{array}$} & \multirow{2}{*}{$\begin{array}{c}\mathrm{Fe} \\
\text { low }\end{array}$} & \multirow{2}{*}{$\begin{array}{c}\mathrm{Fe} \\
\text { high }\end{array}$} & \multirow{2}{*}{$\begin{array}{l}\text { Mn } \\
\text { low }\end{array}$} & \multirow{2}{*}{$\begin{array}{l}\text { Mn } \\
\text { high }\end{array}$} & \multirow{2}{*}{$\begin{array}{l}\mathrm{Zn} \\
\text { low }\end{array}$} & \multirow{2}{*}{$\begin{array}{c}\text { Zn } \\
\text { high }\end{array}$} & \multirow{2}{*}{$\begin{array}{l}\mathrm{Cu} \\
\text { low }\end{array}$} & \multirow{2}{*}{$\begin{array}{l}\mathrm{Cu} \\
\text { high }\end{array}$} & \multirow{2}{*}{$\begin{array}{c}\text { B } \\
\text { low }\end{array}$} & \multirow{2}{*}{$\begin{array}{c}\text { B } \\
\text { high }\end{array}$} \\
\hline & Low & High & & & & & & & & & & & & & & & & & & \\
\hline Overall & 12.0 & 1.7 & 0.64 & 0.51 & 4.83 & 2.83 & 7.64 & 12.87 & 1.66 & 2.03 & 239 & 239 & 1149 & 248 & 20 & 36 & 2.8 & 2.0 & 46 & 21 \\
\hline $\mathrm{pH}$ regime $^{\mathrm{z}}$ & * & & \# & & & & $*$ & $*$ & * & & NS & & * & & * & & & $*$ & * & \\
\hline \multicolumn{21}{|c|}{ Percent lowbush ${ }^{y}$} \\
\hline $25-33$ & 13.5 & 2.7 & 0.58 & 0.48 & 4.47 & 3.11 & 8.45 & 12.59 & 1.93 & 2.05 & 246 & 248 & 915 & 248 & 21 & 34 & 2.8 & 2.4 & 52 & 23 \\
\hline $50-75$ & 15.8 & 2.2 & 0.62 & 0.51 & 4.93 & 3.00 & 7.96 & 13.89 & 1.74 & 2.17 & 225 & 223 & 1135 & 298 & 21 & 42 & 3.1 & 2.0 & 50 & 22 \\
\hline 100 & 9.8 & 1.1 & 0.68 & 0.52 & 4.99 & 2.59 & 7.01 & 12.51 & 1.47 & 1.93 & 243 & 241 & 1292 & 222 & 19 & 33 & 2.6 & 1.8 & 42 & 18 \\
\hline$r^{\mathrm{x}}$ & NS & -0.52 & 0.67 & NS & NS & -0.35 & -0.72 & NS & -0.71 & NS & NS & NS & 0.61 & NS & NS & NS & NS & -0.46 & -0.37 & -0.43 \\
\hline \multicolumn{21}{|c|}{ Correlation of nutrient concentration with $\log _{10}$ dry weight ${ }^{z}$} \\
\hline & --- & --- & -0.40 & 0.29 & 0.50 & 0.72 & 0.03 & -0.30 & 0.08 & -0.15 & -0.28 & 0.04 & 0.03 & 0.37 & -0.05 & 0.20 & 0.01 & 0.46 & 0.40 & 0.28 \\
\hline & & & $*$ & NS & $* *$ & $* *$ & NS & NS & NS & NS & NS & NS & NS & \# & NS & NS & NS & $*$ & $*$ & NS \\
\hline
\end{tabular}

$\overline{z, \#, *, * * F}$ value is $>1$ for $\mathrm{pH}$ regime effects $(P<0.10,0.05$, or 0.01 , respectively) or $r$ not equal to 0 for correlation. NS means not significantly different.

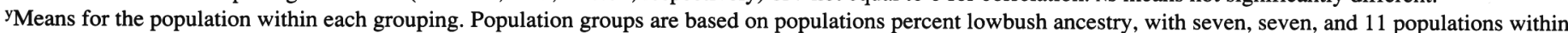
each grouping, respectively.

${ }^{\mathrm{x}}$ The correlation between the percent lowbush ancestry and the nutrient concentration or dry weight. Only $r$ values not equal to 0 ( $P \leq 0.10$; df $=23$ ) are listed. 
Table 5. Mean total content of macro- and micronutrients for the aboveground portion of blueberry plants grown at high (6.5) and low (5.0) pH.

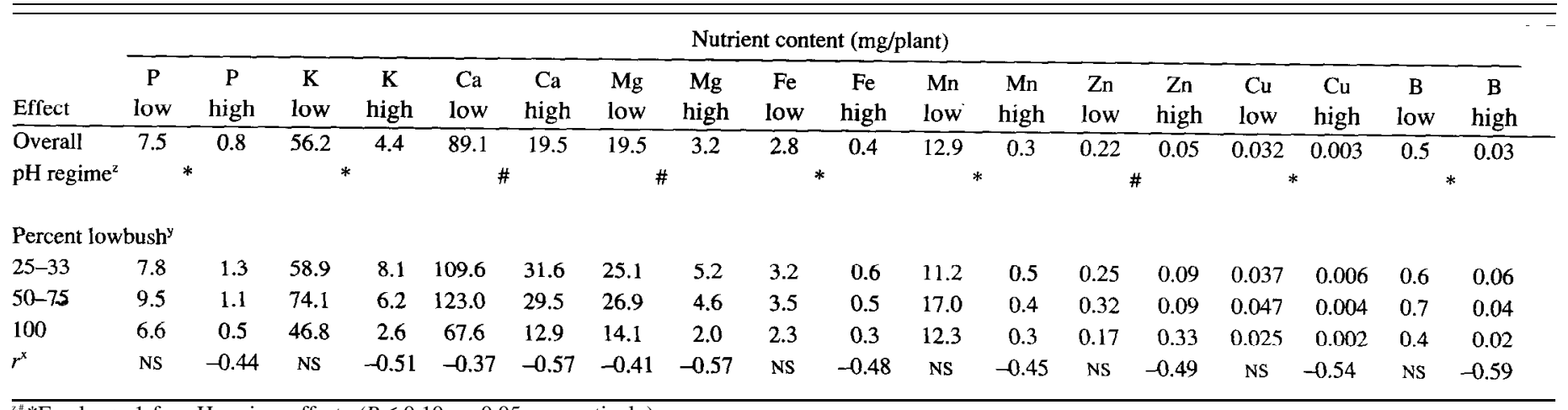

2,H,*F value $>1$ for $\mathrm{pH}$ regime effects $(P \leq 0.10$ or 0.05 , respectively).

${ }^{y}$ Means for the populations within each grouping. Population groupings are based on populations percent lowbush ancestry, with seven, seven, and 11 populations within each grouping, respectively.

${ }^{\mathrm{x}}$ The correlation between the percent lowbush ancestry and the nutrient concentration. Only $r$ values not equal to $0(P \leq 0.10$, df $=23)$ arc listed.

$\mathrm{Ca}, \mathrm{Mg}$, and $\mathrm{B}$ leaf concentrations and percent lowbush ancestry in similar blueberry germplasm. These differences may result from sampling whole plants in the present study rather than only leaves. Populations with a larger percentage lowbush ancestry concentrated $\mathrm{P}$ and $\mathrm{Mn}$ without a higher total content (Tables 4 and 5). Because total content of these elements was not affected, higher concentrations in lowbush germplasm were the result of similar uptake, but lower dry matter production. As the percentage of lowbush ancestry increased, total $\mathrm{Ca}$ and $\mathrm{Mg}$ content decreased at low pH (Tables 4 and 5).

At high $\mathrm{pH}, \mathrm{K}, \mathrm{Cu}$, and $\mathrm{B}$ concentrations decreased as the percentage of lowbush ancestry increased (Table 4). The populations with a higher percentage of lowbush ancestry generally consisted of smaller plants and, thus, had a lower total content of all nutrients (Table 5). Calcium and $\mathrm{Mg}$ were the only nutrients exhibiting lower total content at both $\mathrm{pH}$ levels as the percent lowbush ancestry increased.

The average Mn concentration at low $\mathrm{pH}$ was $1149 \mathrm{mg} \cdot \mathrm{kg}^{-1}$ (Table 3), which was higher than the average levels reported by Korcak et al. (1982) in populations derived largely from $V$. corymbosum, but within the range reported for the $V$. corymbosum cultivar 'Blueray' (Korcak, 1988) and for $V$. angustifolium (Hall et al., 1964; Townsend, 1969). Large variation in Mn concentration is not unusual in Vaccinium (Korcak, 1988). Korcak et al. (1986), Korcak (1988) and Rosen and Luby (1987) associated higher Mn concentration with $V$. angustifolium ancestry. These reports agree with the results from the present experiment at the low $\mathrm{pH}$ regime. However, at high soil $\mathrm{pH}$, the populations had similar Mn concentrations regardless of ancestry and, when expressed as total content, Mn decreased with lowbush ancestry-a function of dry matter accumulation. Thus, mechanisms involving differential accumulation of $\mathrm{Mn}$ appear to be dependent on soil $\mathrm{pH}$.

Another method of evaluating relationships between plant performance and nutrient status was to correlate dry matter accumulation and nutrient concentration over all populations within a $\mathrm{pH}$ regime. Although this relationship may have contributed to significant correlations between lowbush ancestry and nutrient status, as previously discussed, dry matter production and lowbush ancestry were only partially correlated at high $\mathrm{pH}$ and not correlated at low $\mathrm{pH}$. Under the low $\mathrm{pH}$ regime, the correlation between nutrient concentration and dry weight was positive for $\mathrm{K}$ and $\mathrm{B}$ and negative for $\mathrm{P}$ (Table 4). The correlation between nutrient concentration and dry weight was positive $(P \leq 0.10)$ for $\mathrm{K}, \mathrm{Mn}$, and $\mathrm{Cu}$ under the high $\mathrm{pH}$ regime. In previous studies, negative correlations between tissue $\mathrm{K}$ concentration and chlorosis or dry weight accumulation were reported (Cain, 1954, Gupton and Spiers, 1992). Reasons for the positive correlation found in this study are not clear and may be related to the specific germplasm tested or soil type. It is questionable, therefore, whether selection for high tissue concentrations of $\mathrm{K}, \mathrm{Mn}$, or $\mathrm{Cu}$ would assist in the selection of populations with higher dry weight accumulation at higher $\mathrm{pH}$. In addition, as pointed out by Gupton and Spiers (1992) and Finn et al. (1993), visual ratings and nondestructive plant volume measurements were highly correlated with shoot dry weight and may be the only selection criteria needed. Including the nutrient data, however, may help in understanding the response or tolerance mechanisms to higher $\mathrm{pH}$.

For all nutrients, correlations between dry weight and nutrient content were high $(P \geq 0.91$, data not presented) because of the arithmetic relationship between these two traits and the large amount of variation for dry weight (Finn et al., 1993).

In conclusion, the effects of soil $\mathrm{pH}$ on the nutrient status in the plant depended on the populations examined. Therefore, generalizations about plant performance and nutrient concentration of the plant could only be made in the context of a given $\mathrm{pH}$ regime. Plant performance on higher $\mathrm{pH}$ soils appears to be related to concentrations of $\mathrm{Mn}, \mathrm{K}$, and $\mathrm{Cu}$ in the shoots, the significance of which needs further investigation. Although $V$. angustifolium has been proposed as a source of adaptation to upland soil conditions, which can include higher soil $\mathrm{pH}$, the $V$. angustifolium germplasm examined in this study did not exhibit a particular tolerance to higher soil $\mathrm{pH}$ based on dry weight accumulation or nutrient status. Its adaptation to upland soils may result from other factors such as tolerance to drought, fine-textured soils, or low organic matter.

\section{Literature Cited}

Ballinger, W.F. 1966. Soil management, nutrition and fertilizer practices, p. 132-178. In: P. Eck and N.F. Childers (eds.). Blueberry culture. Rutgers Univ. Press, New Brunswick, N.J.

Bray, R.H. and L.T. Kurtz. 1945. Determination of total, organic, and available forms of phosphorus in soil. Soil Sci. 59:39-45.

Brown, J.C. and A.D. Draper. 1980. Differential response of blueberry (Vaccinium) progenies to $\mathrm{pH}$ and subsequent use of iron. J. Amer. Soc. Hort. Sci. 105:20-24.

Cain, J.C. 1954. Blueberry chlorosis in relation to leaf $\mathrm{pH}$ and mineral composition. Proc. Amer. Soc. Hort. Sci. 64:61-70.

Chandler, C.K., A.D. Draper, G.J. Galletta, and J.C. Bouwkamp. 1985. Combining ability of blueberry interspecific hybrids for growth on upland soil. HortScience 20:257-258.

Chandler, C.K., R.F. Korcak, and A.D. Draper. 1984. Analysis of leaf and soil samples from a planting of blueberry seedlings growing on an 
unmulched upland soil. Ohio State Univ. Res. Circ. 283:69-71.

Eck, P. 1988. Blueberry science. Rutgers Univ. Press, New Brunswick, N.J., p. 91-119.

Finn, C.E., J.J. Luby, C.J. Rosen, and P.D. Ascher. 1993. Blueberry germplasm screening at varying soil $\mathrm{pH}$ regimes. I. Plant survival and growth. J. Amer. Soc. Hort. Sci. 118:377-382.

Galletta, G.J. 1975. Blueberries and cranberries, p. 154-196. In: J. Janick and J.N. Moore (eds.). Advances in fruit breeding. Purdue Univ. Press, W. Lafayette, Ind.

Gupton, C.L. and J.M. Spiers. 1992. Inheritance of tolerance to mineral element induced chlorosis in rabbiteye blueberry. HortScience 27: 148151.

Hall, I.V., L.E. Aalders, and L.R. Townsend. 1964. The effects of soil pH on the mineral composition and growth of the lowbush blueberry. Can. J. Plant Sci. 44:433-438.

Haynes, R.J. and R.S. Swift. 1986. The effect of $\mathrm{pH}$ and of form and rate of applied iron on micronutrient availability and nutrient uptake by highbush blueberry plants grown in peat or soil. J. Hort. Sci. 61:287294.

Jones, J.B., B. Wolf, and H.A. Mills. 1991. Preparation and analysis, p. 23-26. Plant analysis handbook. Micro-Macro, Athens, Ga.

Korcak, R.F. 1986a. Adaptability of blueberry species to various soil types: I. Growth and initial fruiting. J. Amer. Soc. Hort. Sci. 111:816-821.

Korcak, R.F. 1986b. Adaptability of blueberry species to various soil types: II. Leaf and soil analysis. J. Amer. Soc. Hort. Sci. 111:822-828.

Korcak, R.F. 1988. Response of blueberry species to excessive manganese. J. Amer. Soc. Hort. Sci. 113:189-193.

Korcak, R.F. 1989. Variation in nutrient requirements of blueberries and other calcifuges. HortScience 24:573-578.

Korcak, R.F., G.J. Galletta, and A.D. Draper. 1982. Response of blueberry seedlings to a range of soil types. J. Amer. Soc. Hort. Sci. 107:11531160.

Lindsay, W.L. and W.A. Norvell. 1978. Development of a DTPA soil test for zinc, iron, manganese, and copper. Soil Sci. Soc. Amer. J. 42:421428.

Munter, R.C., T.L. Halverson, and R.D. Anderson. 1984. Quality assurance for plant tissue analysis by ICP-AES. Commun. Soil Sci. Plant Anal. 15:1285-1322.

Reich, L.A., R.F. Korcak, and A.H. Thompson. 1982. The effect of selected soil factors on growth and nutrient content of highbush blueberry (Vaccinium corymbosum L.). J. Amer. Soc. Hort. Sci. 107:943947.

Rosen, C.J. and J.J. Luby. 1987. Variation in foliar elemental composition in Vaccinium crosses, p.45-51. In: H.W. Gabelman and B.C. Loughman (eds.). Genetic aspects of plant nutrition. Martinus Nijhoff, Boston.

Steel, R.G.D. and J.H. Torrie. 1980. Principles and procedures of statistics: A biometrical approach. 2nd ed. McGraw-Hill, New York, p. 235236.

Thomas, G.W. 1982. Exchangeable cations, p. 159-165. In: A.L. Page (ed.). Methods of soil analysis, Part 2. 2nd ed. Amer. Soc. Agron. Monogr. 9.

Townsend, L.R. 1969. Influence of form of nitrogen and $\mathrm{pH}$ on growth and nutrient levels in the leaves and roots of the lowbush blueberry. Can. J. Plant Sci. 49:333-338.

Townsend, L.R. 1971. Effect of acidity on growth and nutrient composition of the highbush blueberry. Can. J. Plant Sci. 51:385-390. 